University of Nebraska - Lincoln

DigitalCommons@University of Nebraska - Lincoln

1995

\title{
Interaction of Diffuse Competition and Insect Herbivory in Limiting Brittle Prickly Pear Cactus, Opuntia fragilis (Cactaceae)
}

Jutta C. Burger

University of Nebraska - Lincoln

Svata M. Louda

University of Nebraska - Lincoln, slouda1@unl.edu

Follow this and additional works at: https://digitalcommons.unl.edu/bioscilouda

Part of the Ecology and Evolutionary Biology Commons

Burger, Jutta C. and Louda, Svata M., "Interaction of Diffuse Competition and Insect Herbivory in Limiting Brittle Prickly Pear Cactus, Opuntia fragilis (Cactaceae)" (1995). Svata M. Louda Publications. 2.

https://digitalcommons.unl.edu/bioscilouda/2

This Article is brought to you for free and open access by the Papers in the Biological Sciences at DigitalCommons@University of Nebraska - Lincoln. It has been accepted for inclusion in Svata M. Louda Publications by an authorized administrator of DigitalCommons@University of Nebraska - Lincoln. 


\title{
INTERACTION OF DIFFUSE COMPETITION AND INSECT HERBIVORY IN LIMITING BRITTLE PRICKLY PEAR CACTUS, Opuntia fragilis (CACTACEAE) ${ }^{1}$
}

\author{
JutTA C. BurgeR ${ }^{2}$ AND SvaŤA M. LOUdA ${ }^{3}$ \\ School of Biological Sciences and Cedar Point Biological Station, University of Nebraska-Lincoln, \\ Lincoln, Nebraska 68588-0343
}

\begin{abstract}
We tested the effects of above- and belowground competition and evaluated insect herbivory on the growth of a common cactus (Opuntia fragilis) in Sandhills prairie. Our purpose was to determine the independent and joint contribution of these factors to the variation observed in cactus size and local abundance. We manipulated ambient prairie vegetation and surface water availability in a full factorial design. When Opuntia fragilis was released from competition with surrounding vegetation, it grew significantly larger in the second growing season, both in terms of number and size of new cladodes. Ramets grown within live prairie vegetation averaged no net growth. These ramets were also more frequently fed upon by the larvae of two internally feeding cactus insects. As a result, insect herbivory reinforced the competitive suppression of the cactus by grasses. Water supplementation had no significant effect, either on cactus growth or on insect herbivory. We conclude that the mechanism by which dense prairie vegetation influenced net growth of $O$. fragilis was both direct, through competition for nonwater resources such as light, and indirect, through its mediation of feeding by specialized insect herbivores. Furthermore, since the direct growth response to treatment did not precede the indirect effect of habitat-mediated variation in feeding by insects, our results contradict the current expectation that indirect effects require more time to be expressed than do direct effects.
\end{abstract}

Competition can be intense in water-limited grassland ecosystems, and water availability can strongly influence plant community composition (Weaver and Albertson, 1936; Lauenroth, Dodd, and Sims, 1978; Lauenroth, 1979; Barnes and Harrison, 1982). The standing biomass of grasses often correlates strongly with mean annual rainfall, especially where soils have limited water-holding capacity (Sala et al., 1988), such as in Sandhills prairie. Prickly pear cacti (Opuntia spp.) occur throughout the Great Plains grasslands. Increases in their densities have been recorded during and after severe droughts (Cook, 1942; Bement, 1968; Hyder et al., 1975), suggesting that competition with grasses may suppress cacti and directly limit their densities.

Several studies have shown that the dense grass canopies produced in response to heavy rainfall are also associated with decreased densities of Opuntia spp. (Hyder et al., 1975; Dougherty, 1986). However, the mechanism for this shift in abundance is not clear. Competition, belowground for water or nutrients or aboveground for light, could be directly limiting the cacti. Alternately, increases in grass canopy density could lead to increased herbivore load (Cook, 1942; Louda, Keeler, and Holt, 1990; Burger and Louda, 1994). No experimental data yet simultaneously assess these alternative mechanisms

\footnotetext{
${ }^{1}$ Manuscript received 8 December 1994; revision accepted 16 May 1995.

${ }^{2}$ Present address: Department of Entomology, University of California-Riverside, Riverside, California 92521-0314.

${ }^{3}$ Author for correspondence.

The authors thank A. Joern and K. P. Pruess for advice on methods and comments on the manuscript; K. Laumans, D. Lynch, and R. W. Otley for help in the field or with equipment, and The Nature Conservancy for use of Arapaho Prairie. This research was partially funded by the Jessie A. Lee award to J. B. from the University of Nebraska, Lincoln, and equipment from National Science Foundation grant BSR8516515 to S.M.L.
}

for vegetation influence on cactus growth and distribution. In this study, we experimentally examined both direct and indirect effects of prairie grasses on prickly pear growth and propagation.

The influence of water on the abundance of prickly pear cacti is not clearly understood. As succulents, cacti can store relatively large amounts of water and are therefore able to endure long periods of drought (Nobel, 1988). Additionally, as plants with crassulacean acid metabolism (CAM), photosynthesis entails lower daytime transpiration rates than those of most other grassland plants (Szarek and Ting, 1975; Nobel, 1977). Prickly pear cacti, such as the small brittle prickly pear (Opuntia fragilis) that is indigenous to the Sandhills of Nebraska, have extremely shallow roots (Burger, 1994). These roots seldom penetrate below the top $10 \mathrm{~cm}$ of soil. The distribution of roots of cacti in the soil in general reflects the distribution of soil moisture for most cacti and for Agave (Nobel, Miller and Graham, 1992). Additionally, precipitation stimulates production of "rain roots" in many cacti (Nobel, 1988). Temporary increases in cladode thickness have been measured in $O$. polyacantha cladodes after simulated rainfall events of as little as 2.5 mm (Dougherty, 1986). Therefore, Opuntia are able to absorb water from light rains that are virtually inaccessible to more deeply rooted grasses.

No strong correlation between precipitation and growth or density of Opuntia has been found to date. Yet, studies have shown that water augments physiological and developmental processes. Irrigation increases nighttime uptake of $\mathrm{CO}_{2}$ (Hanscom and Ting, 1977; Koch and Kennedy, 1980; Ehleringer and Cooper, 1988; Goldstein et al., 1991). Also, soil moisture can be critical for at least one stage in the life history of succulents: germination and establishment from seed (Jordan and Nobel, 1982; Nobel, 1988). Water availability may therefore contribute 


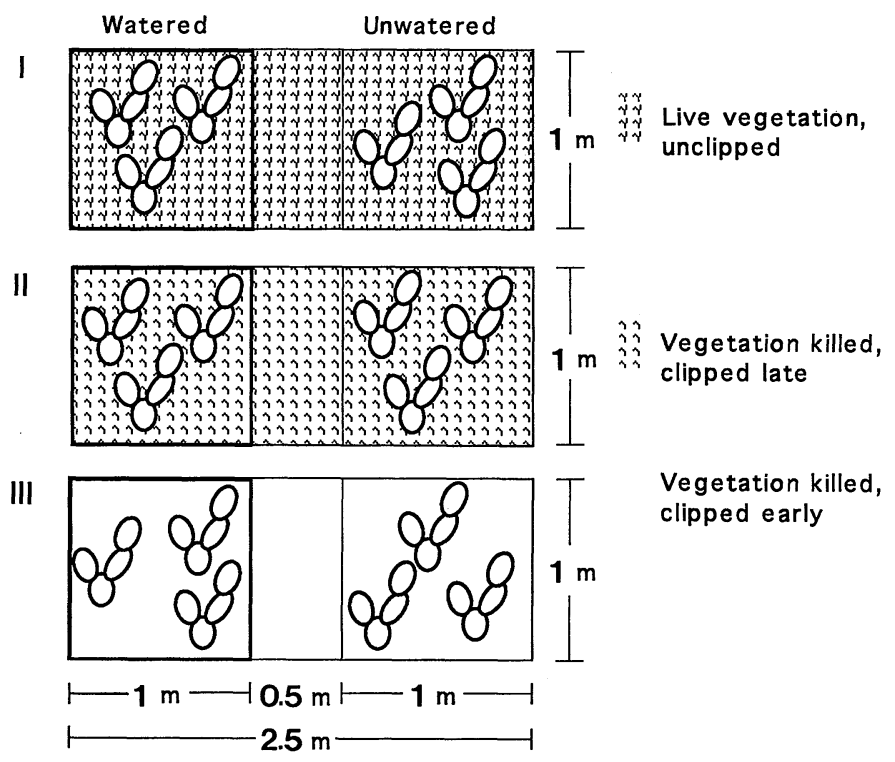

Fig. 1. Split-plot design for a replicate block $(N=14)$ in which both competing vegetation and water availability were manipulated. Two ramets were planted into each split-plot on 8-10 June 1992. A third ramet was added to the experiment on 22 May 1993, but results regarding the added ramets are not presented here. In early 1993, vegetation treatment II was clipped to resemble treatment III. The unvegetated treatments (II and III) were not significantly different, and, thus were pooled for statistical analysis of cumulative effects (see Methods and Table 1).

to limiting the distribution of some species of cacti in deserts (Tschirley and Wagle, 1964; Jordan and Nobel, 1982).

The role of soil nitrogen in cactus population dynamics is also not well understood. Nitrogen availability is generally low in arid and semiarid environments, and it is linked to water availability. Nitrogen can strongly influence plant community structure and standing biomass (Yeaton and Manzanares, 1986; Tilman, 1987). Both small (Hyder et al., 1975) and large (Dodd and Lauenroth, 1975) additions of soil nitrogen decreased densities of $O$. polyacantha over several years. The latter authors suggest that an increase in soil nitrogen availability may favor the grasses, which would further limit both establishment and growth of Opuntia.

Stress tolerators, such as cacti, commonly require high light intensities (Grime, 1979). Opuntia fragilis characteristically occupies early successional stages, such as on rock outcrops in southeastern Manitoba, Canada. Its absence later in succession in Manitoba was assumed to be due to shading from taller plants (Frego and Staniforth, 1986). In the Great Plains, Dougherty (1986) found that removal of aboveground vegetation stimulated a significant increase in the number of the new cladodes initiated on $O$. polyacantha in the second year after clipping.

Finally, alternate explanations to competitive suppression of cactus by grasses are seldom evaluated. The most obvious alternative hypothesis is that other interactions change as grass cover increases. In fact, Cook (1942) proposed that a steady decline in Opuntia populations near Hays, Kansas, in wet years following a major drought, was caused by increases in insect herbivore
TABLE 1. Initial repeated-measures analysis of variance for the cumulative effects of competition and water on net growth of Opuntia fragilis. Growth measurements were square-root transformed prior to analysis. Whole-plot treatments were: I) ambient live vegetation; II) dead vegetation, clipped in 1993; or III) dead vegetation, clipped in 1992. Split-plot treatments were: watered weekly; or unwatered. Source of transplants, from either greenhouse or field, was initially treated as a split-split-plot factor ( $T=$ time, $R=$ replicate, $V=$ vegetation, $W=$ water, and $S=$ source of transplant).

\begin{tabular}{lrccc}
\hline \hline \multicolumn{1}{c}{ Source of variation } & df & MS & $F$ & $<P$ \\
\hline Time $\times$ Replicate & 52 & 0.975 & 2.24 & 0.01 \\
Time $\times$ Vegetation & 8 & 3.908 & 8.99 & 0.01 \\
$\quad$ Error 1 [ $\times \mathrm{V} \times \mathrm{R}]$ & 104 & 0.435 & & \\
Time $\times$ Water & 4 & 0.064 & 0.15 & 0.97 \\
$\mathrm{~T} \times \mathrm{V} \times \mathrm{W}$ & 8 & 0.320 & 0.77 & 0.64 \\
Error $2[\mathrm{~T} \times \mathrm{R} \times \mathrm{W}(\mathrm{V})]$ & 156 & 0.417 & & \\
Time $\times \mathrm{Source}$ & 4 & 1.536 & 3.39 & 0.01 \\
$\mathrm{~T} \times \mathrm{S} \times \mathrm{V}$ & 8 & 0.958 & 2.11 & 0.04 \\
$\mathrm{~T} \times \mathrm{S} \times \mathrm{W}$ & 4 & 0.223 & 0.49 & 0.75 \\
Error $3[\mathrm{~T}]$ & 312 & 0.453 & & \\
\hline
\end{tabular}

pressure as grass cover increased. He, and several others since (e.g., Bugbee and Riegel, 1945; Houston, 1963; Myers, 1981) hypothesized that dense grass cover provided more favorable microhabitat for the insect herbivores of Opuntia. One recent experiment provides support for this hypothesis (Burger and Louda, 1994). Although many studies have suggested this phenomenon as a possible controlling factor for Opuntia populations (Dodd, 1940; Dougherty, 1986), few have quantified insect herbivory on study plants in relation to competitive context (but see Houston, 1963; Myers, 1981). None of these studies, however, recorded both insect herbivore feeding and plant response to experimental manipulations of resources, such as water and light.

The aim of this experiment was to test the effect of competition for water and light on $O$. fragilis directly and to record changes in insect feeding in relation to the manipulations. If water is limiting competitive dominance of grasses over cacti, then addition of water to vegetated plots should reduce cactus growth relative to controls by favoring grasses. If water is limiting the cactus $O$. fragilis, then the addition of water to plots cleared of competing grasses should enhance cactus growth relative to unwatered plots. Alternately, if light is directly limiting the cactus, then the removal of aboveground grass cover should enhance cactus growth, regardless of water availability. In addition, if the main insect herbivore, the moth borer Melitara dentata (Lepidoptera: Pyralidae, Phycitinae), favors moister microhabitats as suggested (Dodd, 1940; Cook, 1942), then herbivory should be more frequent and severe on cacti within the vegetation, especially where water is supplemented. Conversely, removal of surrounding grasses should reduce both moth occurrence and damage on $O$. fragilis.

\section{MATERIALS AND METHODS}

Study site-This experiment was conducted at Arapaho Prairie in the Sandhills of western Nebraska. The prairie is a 526-ha preserve owned by The Nature Conservancy and managed by Cedar Point Biological Station, University of Nebraska-Lincoln. The prairie is maintained 


\section{a. Greenhouse Transplants}

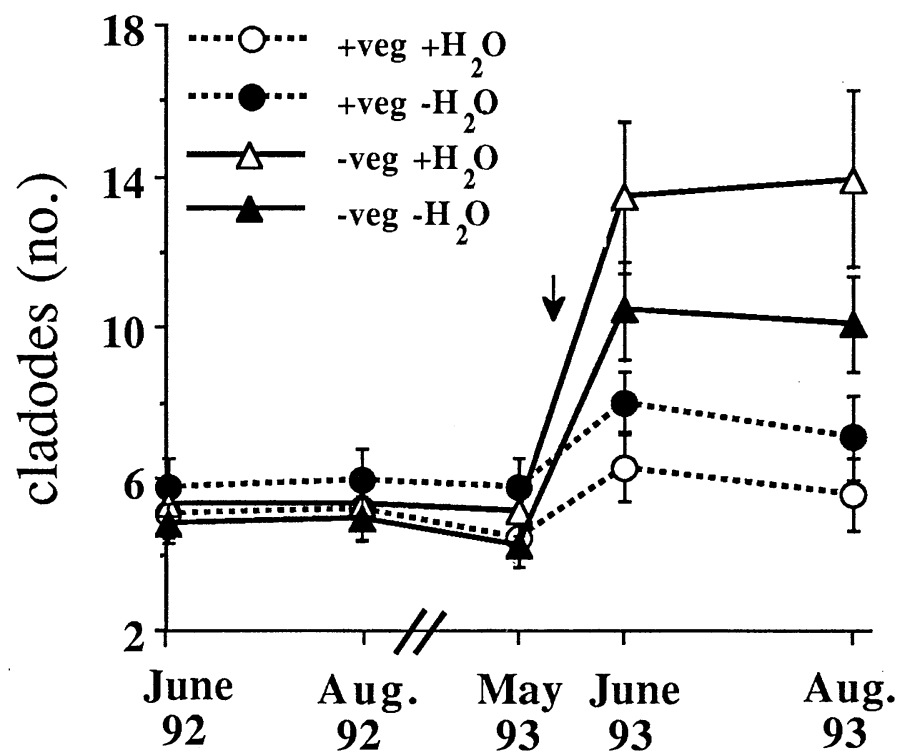

b. Field Transplants

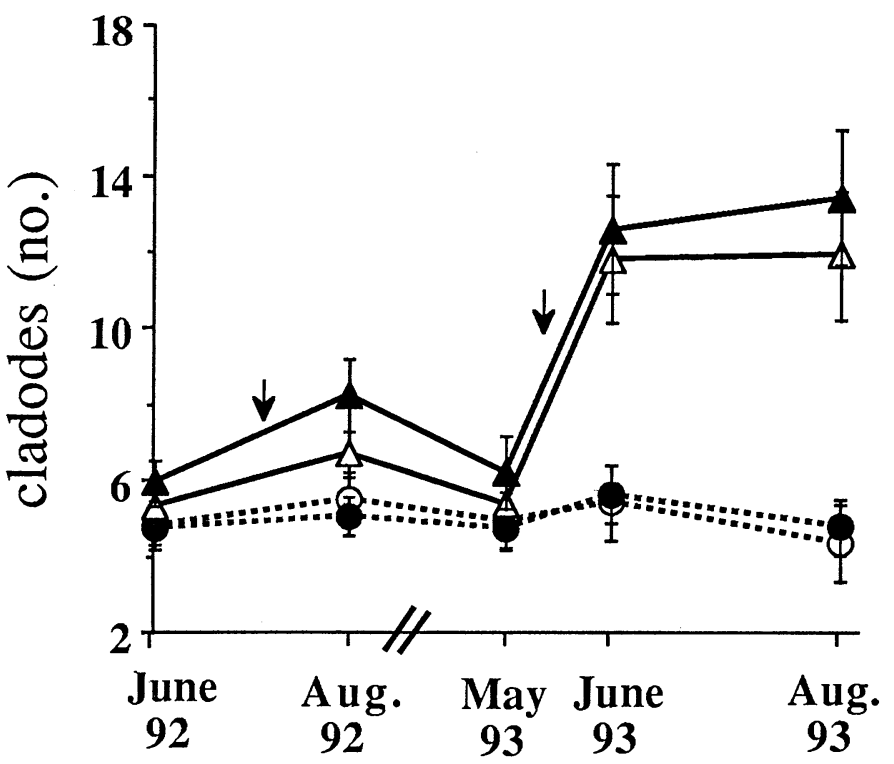

Fig. 2. Net growth of Opuntia fragilis with competition from prairie vegetation and without competition after vegetation had been killed, both with- and without supplemental water. The "no vegetation" category was pooled from clipped, herbicided vegetation (treatment III) and herbicided vegetation left standing until May 1993 (treatment II). Treatment effects of both regimes were similar (ANOVA: Time $\times$ treatment II vs. III contrast, $\left.F_{1,104}=0.43, P=0.79\right)$. $\downarrow=$ significant time $X$ vegetation treatment interaction.
TABLE 2. Repeated-measures ANOVA contrasts between vegetated (I) and unvegetated (II + III) treatments for net growth of transplanted Opuntia fragilis ramets. Growth was the total number of live cladodes over time, from June 1992 to August 1993. The vegetated treatment was live vegetation, or above- and belowground competition; the unvegetated treatment was dead, clipped vegetation, or release from belowground competition. Cladode counts were square-root transformed before analysis.

\begin{tabular}{|c|c|c|c|c|}
\hline Contrast & df & MS & $F$ & $<P$ \\
\hline \multicolumn{5}{|l|}{ Greenhouse transplants } \\
\hline Time (cumulative) $)^{\mathrm{a}}$ & 4 & 3.362 & 9.98 & 0.01 \\
\hline Jun-Aug $1992^{\mathrm{b}}$ & 1 & 0.001 & 0.01 & 0.92 \\
\hline Aug 1992-May 1993 & 1 & 0.002 & 0.00 & 0.96 \\
\hline May-Jun 1993 & 1 & 8.889 & 13.47 & 0.02 \\
\hline Jun 1993-Aug 1993 & 1 & 0.492 & 1.22 & 0.28 \\
\hline \multicolumn{5}{|l|}{ Field transplants } \\
\hline Time (cumulative) ${ }^{\mathrm{a}}$ & 4 & 4.465 & 9.31 & 0.01 \\
\hline Jun-Aug 1992b & 1 & 1.010 & 6.77 & 0.02 \\
\hline Aug 1992-May 1993 & 1 & 2.319 & 2.94 & 0.10 \\
\hline May 1993-Jun 1993 & 1 & 12.267 & 23.15 & 0.01 \\
\hline Jun 1993-Aug 1993 & 1 & 2.367 & 3.55 & 0.08 \\
\hline
\end{tabular}

${ }^{\mathrm{a}}$ Error term $=$ Time $\times$ Vegetation $\times$ Replicate interaction; $\mathrm{df}=104$

${ }^{\mathrm{b}}$ Error term $=$ Vegetation $\times$ Replicate interaction (Time); $\mathrm{df}=26$.

through periodic haying. Arapaho Prairie is characteristic of Sandhills mixed-grass prairie (Keeler, Harrison and Vescio, 1980). Common grass species at our study site were Agropyron smithii, Bouteloua gracilis, Calamovilfa longifolia, Sporobolus sp., and Stipa comata. The soil is predominantly Valentine Fine (VaF) sand (USDA Soil Conservation Service, 1977).

Study species-Opuntia fragilis (Nuttall) Haworth is a small-statured prickly pear cactus, typically $10 \mathrm{~cm}$ or less in height. It is most common on the slopes of stabilized dunes, but it also occurs at lower densities in the valleys and on the ridgetops of the Sandhills. Prairie grasses can grow to form a dense canopy, overtopping $O$. fragilis by late summer (J. C. Burger, personal observation). Opuntia fragilis ramets are independently rooted shoots composed of modified stem segments, or cladodes. New cladodes are initiated from the nodes below terminal or subterminal cladodes each spring and have usually expanded fully and matured by early July. Opuntia fragilis rarely reproduces sexually at Arapaho Prairie, but instead propagates itself vegetatively via fragmentation (J. C. Burger, personal observation). Both physical disturbance and feeding by insects can sever the cladode connection to the parent plant. Loose cladodes that land on soil often root, producing new ramets.

Insect herbivores-The three most common insect herbivores on $O$. fragilis at Arapaho Prairie (J. C. Burger, personal observation) are: 1) a specialist pyralid moth borer, Melitara dentata (Grote) (Heinrich, 1939; Dodd, 1940; Mann, 1969); 2) a specialist stem-boring curculionid weevil, Gerstaeckeria sp. Champion (O’Brien, 1970); and 3) a specialist coreid sucking bug, Chelinidea vittiger Uhler (Dodd, 1940; Mann, 1969). The moth borer is the most destructive herbivore to $O$. fragilis locally (J. C. Burger, personal observation). Larvae feed internally, leaving hollowed cladodes and small mounds of frass upon exiting a ramet (S. M. Louda and J. C. Burger, personal observation). Each larva consumes several cladodes before pupation. When ramets are incompletely consumed, the live, loose cladodes that remain may root (J. C. Burger, unpublished data). Adults of the moth do not feed. Larvae of the weevil Gerstaeckeria sp. also feed internally; however, individual larvae appear to consume only one or two cladodes before pupating (J. C. Burger, personal observation). Cladodes containing a weevil larva appear brown and mushy (J. C. Burger, personal observation). Adults of the weevil are external feeders whose feeding produces small $(=3 \mathrm{~mm})$ pits on cladode surfaces. Both nymphs and adults of the sucking bug $C$. vittiger 

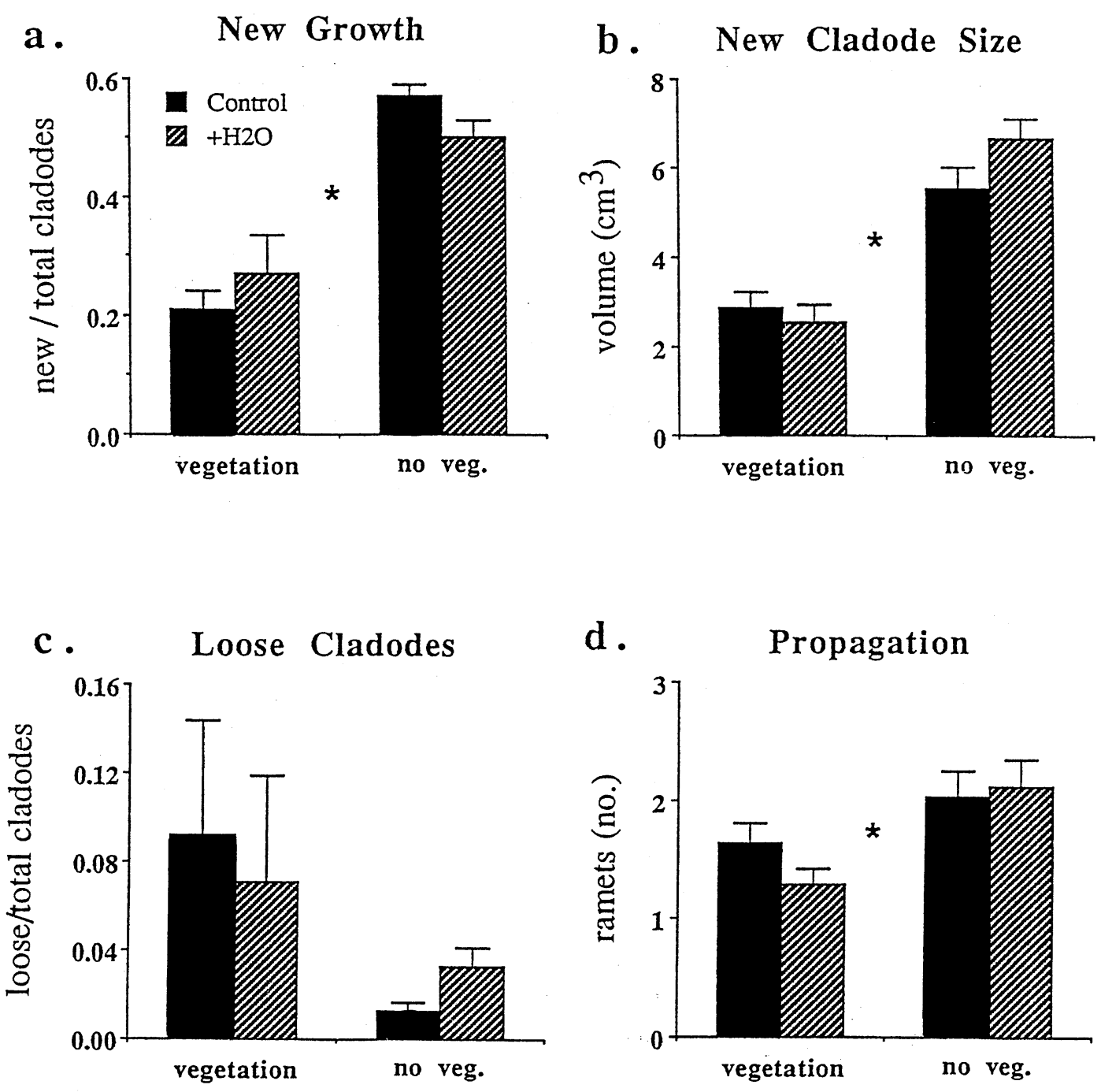

\section{Competition Treatment}

Fig. 3. Characteristics of $O$. fragilis in the competition and water treatments after two growing seasons (August 1993), including: (A) new growth; (B) cladode size; (C) loose cladodes; (D) and propagation $(*=P<0.05)$.

are external feeders. Their feeding causes conspicuous chlorotic rings on cladode surfaces (Cook, 1942).

Experimental design-Fourteen areas with similar exposure were arbitrarily chosen on a swale at Arapaho Prairie. These areas were treated as replicate blocks (Barnes and Harrison, 1982). Three $1 \times 2.5 \mathrm{~m}^{2}$ plots were established in each block. Each of these plots was divided into two $1-\mathrm{m}^{2}$ split-plot subunits separated by $0.5 \mathrm{~m}^{2}$ (Fig. 1). We transplanted cacti into these plots in June 1992 and monitored cactus response and insect feeding over two subsequent growing seasons $(1992,1993)$.

We initiated six competition treatments within each block, altering either aboveground vegetation, belowground vegetation, or neither, and adding water or not. The vegetation treatments that were randomly assigned among the three plots within each block consisted of: I) unmanipulated vegetation, which served as a control; II) herbicided vegetation left in situ, which reduced belowground competition for water and nutrients while initially maintaining aboveground competition for light; and
III) herbicided and clipped vegetation, which removed both above- and belowground competition (Fig. 1). During the first season, the cover of dead, standing vegetation in treatment II became too patchy to adequately represent aboveground competition for light. Therefore, early in the second season (1993), treatment II was modified to resemble treatment III by clipping all of the remaining aboveground, dead vegetation.

Vegetation treatments were initiated on 28 May 1992 by applying herbicide (Roundup: Monsanto; Glyphosate: N-[phosphonomethyl]glycine) to plots assigned to treatments II and III. Ten days after applying herbicide, we clipped all plots receiving treatment III. Treatment integrity was maintained by spot herbiciding on 29 July 1992 and 9 June 1993, and by hand-weeding on 20-21 June 1993. Water treatments were started on 10 June 1992 by adding water ( $2 \mathrm{gal} / \mathrm{wk}$ ) to one of each pair of the subunits within each plot as a split-plot treatment. The water treatment simulated additional light rainfall events during the growing season that would wet the shallow $(<10 \mathrm{~cm}$ depth) primary root zone of Opuntia. The treatment increased precipitation by $2.8 \mathrm{~cm} /$ 


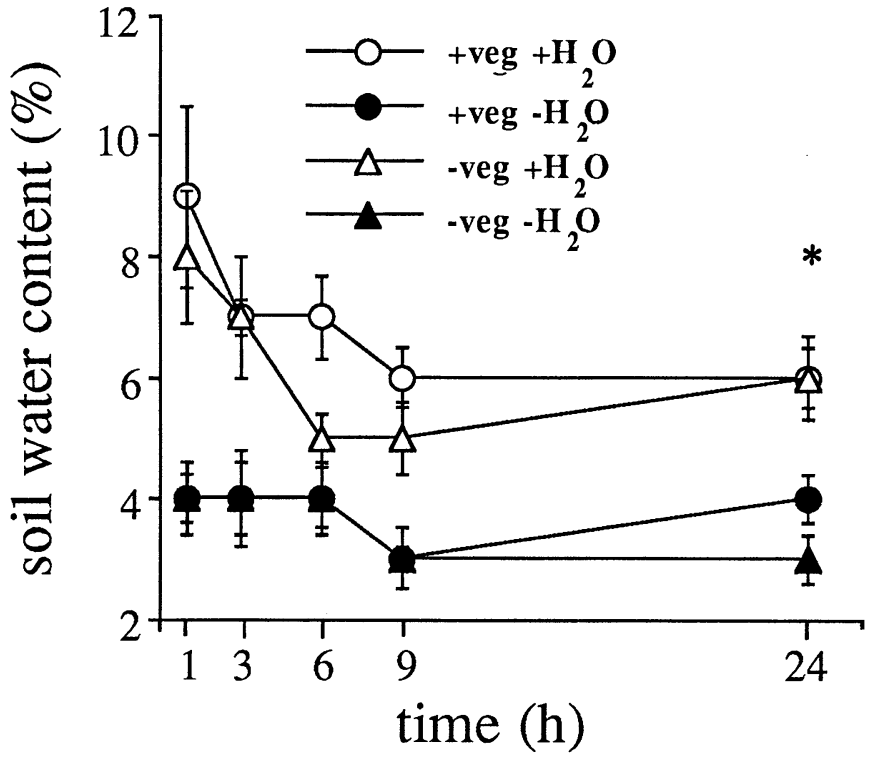

Fig. 4. Soil moisture decline after watering plots with vs. without ambient vegetation $(N=3$ subsamples $\times 3$ replicates $\times 4$ treatments $\times 5$ times $=180), 4$ September $1993(*=P<0.05)$.

mo. Average monthly precipitation in Arthur County, Nebraska, is 8.8 $\mathrm{cm}$ in May, $8.5 \mathrm{~cm}$ in June, and 7.6 in July (Wilhite and Hubbard, 1989). Split-plots receiving water treatments were watered by hand every 6-10 d. In 1992, we watered from 19 June to 19 August, and on 12 September, 25 September, and 3 October. In 1993, water was applied from 15 May to 8 August. We waited a minimum of $1 \mathrm{~d}$ after any natural rainfall to apply water in order to maximize the effect of an experimental addition of water.

On 8-10 June 1992, we transplanted two ramets of $O$. fragilis into each split plot and removed any cacti that had been previously growing in plots. One ramet was grown in the greenhouse, and the second was collected from prairie adjacent to the preserve. All greenhouse transplants had been collected as ramets from the Sandhills in February 1992. Transplants of each type were paired by size across the split-plot subunits of a plot to minimize subsequent differences correlated with initial ramet size. A ramet pair was randomly assigned to each plot, and each ramet within a pair was randomly assigned to a split-plot subunit. Greenhouse-grown plants were enclosed in a wire mesh cage in 1992 to prevent herbivory until transplants had established. We removed the cages in August 1992, prior to the fall flight and oviposition period of the moth borer Melitara dentata. We transplanted an additional ramet from an adjacent prairie into each split-plot on 22 May 1993. Since single-season treatment effects on these added transplants were similar to first-year growth responses of ramets tranplanted in 1992 (Burger, 1994), the added ramets are not discussed here (see Burger, 1994). We also planted ramets where transplants from 1992 had died $(N=16)$ in order to retain uniform plant densities in all plots. The replacement ramets were not used for final statistical analysis of growth over two seasons.

Initially (11 June 1992), we measured the size of each newly transplanted ramet by recording the number of cladodes and the length of the longest 1-yr-old cladode. At the end of each growing season (1517 August 1992, 13-15 August 1993), we measured length, width, and thickness of the longest new current-year cladode associated with each original ramet. The following equation was used to obtain a multivariate estimator of the size attained by new cladodes (Burger and Louda, 1994), with $V=$ cladode volume, $L=$ cladode length, $W=$ cladode width, and $T=$ cladode thickness:

$$
\begin{gathered}
V_{\text {new }}=\exp [-0.61+1.17 \cdot \ln (L)+0.81 \cdot \ln (W)+1.1 \cdot \ln (T)] \\
\left(R^{2}=0.94\right) .
\end{gathered}
$$

In addition, we recorded the number of ramets and cladodes associated with each original ramet, as well as the numbers of new, loose, and dead cladodes. In May, June, and August 1993, we tallied evidence of feeding by moth and weevil larvae and by the sucking bugs. In August 1993, we also measured feeding intensity by Gerstaeckeria adults by counting the number of feeding scars on new cladodes.

Soil moisture content was calculated for both watered and unwatered treatments, with and without vegetation, in order to determine the extent to which water supplementation increased surface soil moisture. On 4 September 1993 (9:00 a.m.), we watered one subunit of three arbitrarily selected vegetated (I) and unvegetated (III) treatment plots, and left one subunit unwatered. We collected three soil samples from each split-plot at $1,3,6,9$, and $24 \mathrm{hr}$ after initial water application $(N=156$ samples total). Soil was collected to $10 \mathrm{~cm}$ depth and placed in preweighed, airtight soil cans $(7.5 \mathrm{~cm}$ diameter $\times 5 \mathrm{~cm}$ depth). We weighed samples within $3 \mathrm{hr}$ of collecting them in the field, then oven-dried them at 70 $\mathrm{C}$ overnight, and recorded dry weights. We calculated water content as the proportion of water in the sample, by weight.

Statistical analysis-Cumulative net growth was measured as the change in number of live cladodes originating from a transplanted ramet over two growing seasons, from June 1992 to August 1993. We analyzed cumulative net growth using a multivariate repeated-measures model for a split-plot design (PROC GLM, REPEATED statement; SAS, 1985; von Ende, 1993). Cladode counts for each measurement period were square-root transformed to homogenize variances. Competition and water treatments were arranged in a full factorial design, with competition as the whole-plot treatment and water as the split-plot treatment. Initially, we included transplant origin, i.e., the greenhouse or the field, as a split-split-plot factor. After determining that growth responses among ramets differed significantly by origin in 1992 (Table 1 ), we analyzed their growth over time separately. Since net growth of the two transplant types no longer differed significantly during the second growing season (June-August 1993; $F_{1,312}=0.12, P=0.735$ ), we pooled final treatment responses of both transplant types in August and treated them as subsamples of a split-plot design to assess final treatment reponse.

For 1992, we compared the effect on cactus growth of standing, dead vegetation (treatment II) that was removed in 1993 to that of clipped, dead vegetation (treatment III). Opuntia fragilis did not respond differently to these two treatments (ANOVA: $F_{4,104}=0.43, P=0.80$ ), possibly because the dead vegetation visibly thinned over the growing season. Therefore, for all further analyses including parametric and nonparametric tests, we pooled those two treatments and limited comparisons between competition treatments to: (1) vegetated (treatment I), representing both above- and belowground competition, vs. (2) unvegetated (treatment II + III), representing neither above- nor belowground competition.

In addition, we compared frequency of herbivory among treatments using three-way contingency tables for the main effect of competition and water (PROC CATMOD, SAS, 1985; K. M. Eskridge, personal communication, University of Nebraska). Specific contrasts were used to compare occurrence between the vegetated and unvegetated competition treatments. For both $M$. dentata and $C$. vittiger, the frequencies of feeding were pooled for August 1992 through August 1993. Evidence of feeding by Gerstaeckeria larvae was pooled from May through August 1993. Frequencies of feeding by Gerstaeckeria adults were only compared for new cladodes in August 1993 in order to ensure that the evidence of feeding (pits or scars) was not the result of feeding before the experiment had begun. We obtained estimates of feeding intensity by Gerstaeckeria adults by dividing the total number of feeding scars found on new tissue for a plant by the total number of new cladodes associated with that plant. Scars per new cladode were rank-transformed 

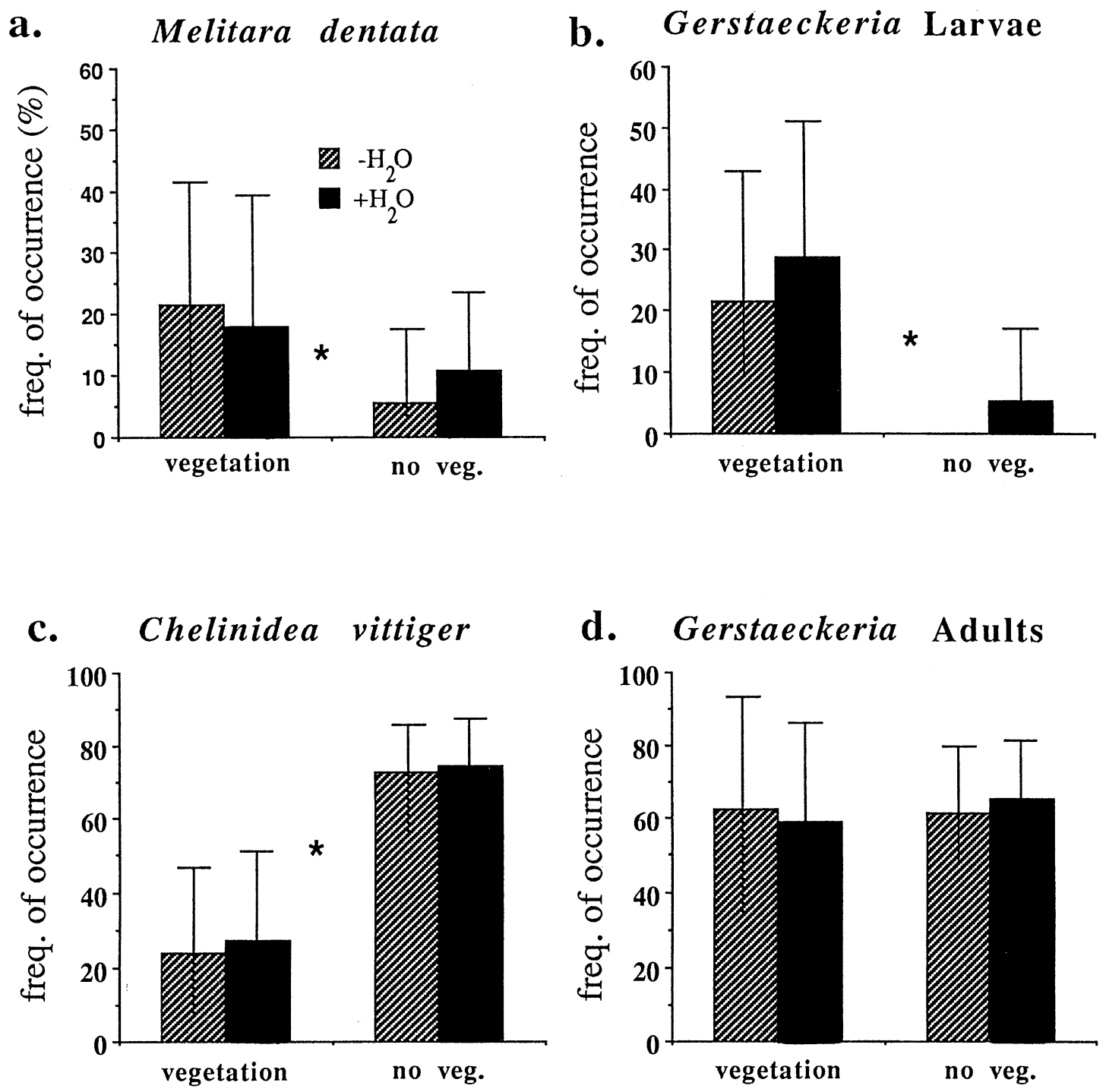

Fig. 5. Frequency of feeding on $O$. fragilis by specialist insect herbivores. Frequencies are cumulative estimates of occurrence on treatment plants over two growing seasons: (A) Melitara dentata (Lepidoptera: Pyralidae) larval feeding; (B) Gerstaeckeria sp. (Coleoptera: Curculionidae) larval feeding; (C) Chelinidea vittiger (Hemiptera: Coreidae) larval and adult feeding; (D) Gerstaeckeria sp. adult feeding on new growth. Cumulative frequencies of treatment-related occurrence over two growing seasons were tested using contingency table analysis $(*=P<0.05)$.

to reduce skew, and ranks were compared by ANOVA using the splitplot design described above.

\section{RESULTS}

Plant response-Cumulative net growth of $O$. fragilis, measured as the increase in number of live cladodes over $2 \mathrm{yr}$, was higher when competing vegetation was completely removed, both for greenhouse (Fig. 2A) and field (Fig. 2B) transplants. However, treatment effects were not clear until the second (1993) growing season (Table 2). Ramets also only grew early in the second season, between May and June 1993; production of new cladodes ceased by mid- and late summer in all treatments (Table 2). Consequently, final differences between competition treatments (Table 2) were primarily the result of changes in plant size between May and June 1993 for both greenhouse and field transplants (Fig. 2).
In year 2, allocation to new growth, represented as the proportion of cladodes that were new, was significantly greater in the absence of vegetation than where live vegetation had been left standing (ANOVA $F_{1,13}=86.89, P$ $<0.01$; Fig. 3A). New cladodes produced during the second growing season were also larger without competing vegetation (ANOVA $F_{1,13}=27.9, P<0.01$; Fig. 3B). Ramets grown without surrounding vegetation were larger, since they were composed of more cladodes (Fig. 2).

The average number of cladodes that dislodged during the study was significantly correlated with ramet size (Pearson's rho $=0.22, P<0.01$ ). However, the proportion of cladodes that dislodged was statistically similar among treatments despite the larger ramets in the unvegetated plots $\left(\chi^{2}{ }_{1}=2.23, P<0.14\right.$; Fig. 3C). More loose cladodes apparently rooted successfully in the absence of surrounding grasses (ANOVA on square-root trans- 


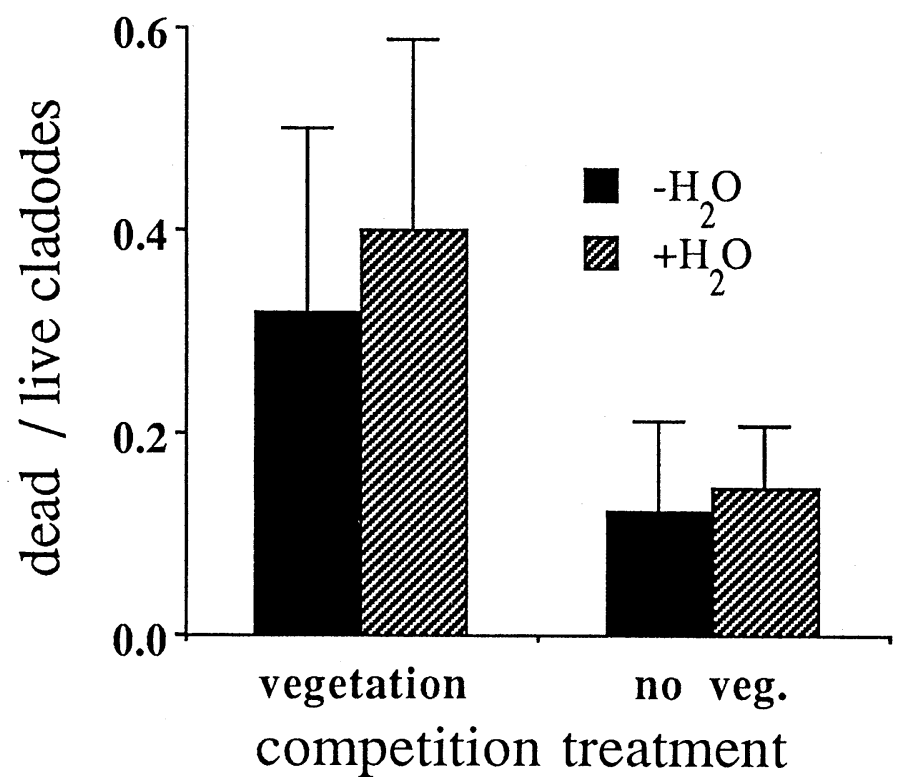

Fig. 6. Association of cladode mortality with feeding intensity of $O$. fragilis. Estimates of cladode mortality are cumulative counts of dead cladodes for treatments over $2 \mathrm{yr}$ and represent mostly death due to feeding by moth and weevil larvae.

formed proportionate increase in number of ramets: $F_{1,13}$ $=4.76, P<0.05$; Fig. 3D).

The water treatment failed to consistently affect any measured parameter of growth of $O$. fragilis in either control or competition treatments, either within a year or cumulatively. Overall, net growth (Fig. 2A, B), allocation to new growth (Fig. 3A), and new cladode volume (Fig. 3B) were independent of water supplementation under all vegetation treatments. However, water applications did significantly increase soil moisture in the top $10 \mathrm{~cm}$ of soil, the primary root zone of $O$. fragilis. One hour after watering, soil water content in watered plots was twice that of unwatered plots, in both vegetated and unvegetated treatments (Fig. 4). Watered plots remained moister for at least $24 \mathrm{hr}$ after water had been applied (ANOVA water content: $F_{1,30}=29.85, P<0.01$; Fig. 4). A light rainfall and lower evapotranspiration at night may have reduced water loss between 9 and $24 \mathrm{hr}$ after watering.

Internal herbivory by moth and weevil larvae-A significantly greater proportion of $O$. fragilis patches in the vegetated treatment were fed upon by larvae of both the moth borer (Melitara dentata: $\chi^{2}{ }_{1}=3.94, P<0.05$; Fig. 5A) and the weevil (Gerstaeckeria sp.: $\chi^{2}{ }_{1}=77.07, P<$ 0.01 ; Fig. 5B) than where the vegetation had been cleared. This occurred even though plant growth rates in the vegetated plots were lower (Fig. 3A) and cladodes were smaller (Fig. 3B). Feeding by larvae left dead, hollowed cladodes, and it was the major cause of cladode death. In 1993, the cumulative number of cladodes that had died was significantly correlated with larval feeding (Pearson rho $=0.21, P=0.02$ ). Although this cladode mortality tended to be greater in densely vegetated plots (Fig. 6), variance in mortality was high and differences were not statistically significant (ANOVA on rank-transformed data: $\left.F_{1,13}=0.28, P=0.60\right)$. Addition of water

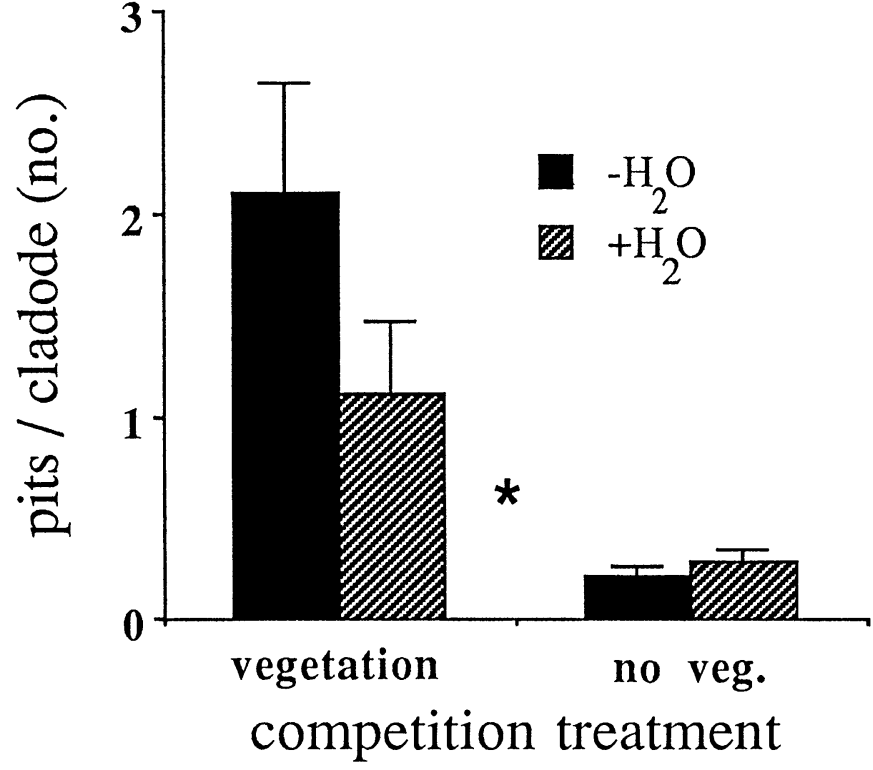

Fig. 7. Intensity of feeding by weevil adults on new cladodes, estimated by the average number of feeding scars per new cladode on a ramet $(*=P<0.05)$.

had no effect on the frequency of feeding by either insect (Fig. 5A, B).

External herbivory by coreid bugs and adult weevils-Nearly three times as many $O$. fragilis patches in the unvegetated treatment were fed upon by nymphal and adult coreid sucking bugs (Chelinidea vittiger) as in live, standing vegetation (Fig. 5C). Supplemental water did not affect feeding by the coreid, either with or without vegetation around the cacti (Fig. 5C). In addition, weevil adults fed on $\approx 80 \%$ of all patches of cacti that contained new growth, independent of vegetation treatment (Fig. 5D). The intensity of feeding by these adult weevils appeared higher on ramets within the ambient vegetation than on ramets in the open, unvegetated plots (ANOVA on ranked average feeding intensity: $F_{1,11}=4.59, P<$ 0.06; Fig. 7). Again, supplemental water had no significant effect on either frequency (Fig. 5D) or intensity (Fig. 7) of attack by adult weevils.

\section{DISCUSSION}

When surrounding grassland vegetation was eliminated, growth of Opuntia fragilis increased dramatically in the 2nd yr. Ramets grew more cladodes (Fig. 2), and cladodes were larger (Fig. 3A, B). The higher proportion of new cladodes in the open in 1993 contributed to a greater net increase in number of cladodes (Fig. 2). Changes in ambient vegetation density did not strongly affect growth until the 2nd yr of the experiment (Table 2). Clearly, competition with grasses was an important component in the dynamics of $O$. fragilis in this grassland. However, small-scale, transient changes in vegetation structure did not alter patterns of growth of $O$. $\mathrm{fra}$ gilis immediately, likely because of the limited early-season growing period available for $O$. fragilis in which to respond (Table 2). 
Supplemental water, applied during both growing seasons, did not significantly affect any growth parameter of $O$. fragilis that was measured. The lack of a direct effect of water is consistent with other studies of cacti in the Great Plains (e.g., Dougherty, 1986; Hyder et al., 1975). Water may only be important indirectly, when it affects grass growth and, subsequently, the incident light environment for Opuntia. Since both 1992 and 1993 were wet summers in the Sandhills (High Plains Regional Climate Center, University of Nebraska, Lincoln, NE, 1994), this experiment may underestimate the importance of water in drier years. Importantly, the lack of an effect of added water and the dramatic growth response of $O$. fragilis to removal of vegetation in year 2 provide evidence that there is strong, aboveground competitive pressure on $O$. fragilis in prairie grasslands. The results suggest that ramets cannot proliferate in densely vegetated habitats over time, but rather require periodic disturbance of the surrounding grass canopy to establish and grow.

This study provides evidence for two contributing mechanisms: direct competition with grasses for light and indirect facilitation of insect herbivores by denser stands of grass. Dense vegetation not only inhibited growth directly by aboveground shading, but it also altered local patterns of feeding by insects on cactus (Fig. 5). Larvae of the stem-feeding moth Melitara dentata and the weevil Gerstaeckeria sp. were the major causes of cladode death within a growing season at Arapaho Prairie (Burger and Louda, 1994). They were significantly more common on plants in dense grass, thereby providing a mechanism for the indirect effect of vegetation on cactus growth. The third major herbivore, the sap-sucking hemipteran Chelinidea vittiger, occurred most often on cacti in unvegetated plots. However, this insect did not measurably reduce its host's growth (J. C. Burger, personal observation).

The increase in insect herbivory in response to the manipulation of vegetative cover draws attention to indirect effects that could be missed with a narrow focus on a specific direct effect. Rates of herbivory often vary significantly in relation to the ambient light environment (e.g., Lincoln and Langenheim, 1979; Louda and Rodman, 1983a, b; Louda, Dixon, and Huntly, 1987; Louda, Farris, and Blua, 1987; Louda, Huntly, and Dixon, 1987; Collinge and Louda, 1988). When habitat-dependent herbivory also strongly affects plant performance, as feeding by insect larvae did for $O$. fragilis, then consideration of only the direct competitive interaction will provide an unrealistic and inaccurate understanding of host plant population dynamics.

Thus, we conclude that the failure of cacti to grow in plots with competing vegetation (Fig. 2) was the combined result of two processes: lower growth rate in competition with surrounding grasses (Fig. 2) and higher cladode mortality caused by insects in dense grass (Figs. $5,6)$. Other experimental evidence supports the hypothesis of indirect effects in this system (Burger and Louda, 1994). Experimental manipulation of only aboveground shading in situ showed that prairie vegetation cover depressed growth of $O$. fragilis, both directly by asymmetric competition and indirectly by facilitating higher damage by specialist insect herbivores. Thus, two processes that are usually contrasted in their effects operated synergistically to depress the cacti within grassland.

Finally these data, together with those of Burger and Louda (1994), contradict the expectation that indirect effects should require more time than direct effects to be expressed (Strauss, 1991). The direct effect of competition took longer to be expressed in this interaction than did the related indirect effect of increased insect herbivore pressure with altered canopy structure.

\section{LITERATURE CITED}

Barnes, P., And A. T. Harrison. 1982. Species distribution and community organization in a Nebraska Sandhills mixed prairie as influenced by plant/soil-water relationships. Oecologia 52: 192-201.

BEMENT, R. M. 1968. Plains pricklypear: relation to grazing intensity and Blue grama yield on central Great Plains. Journal of Range Management 21: 83-86.

Bugbee, R. E., AND A. RIEgEL. 1945. The cactus moth Melitara dentata (Grote), and its effect on Opuntia macrorhiza in western Kansas. American Midland Naturalist 3: 117-127.

Burger, J. C. 1994. Cumulative effects of grassland vegetation and insect herbivores on Opuntia fragilis (Cactaceae). Master's thesis, University of Nebraska. Lincoln, NE.

- , AND S. M. LouDA. 1994. Indirect versus direct effects of grasses on growth of a cactus (Opuntia fragilis): insect herbivory versus competition. Oecologia 99: 79-87.

Collinge, S. K., AND S. M. LoudA. 1988. Herbivory by leaf miners in response to experimental shading of a native crucifer. Oecologia 75: 559-566.

Cook, C. W. 1942. Insects and weather as they influence growth of cactus on the central Great Plains. Ecology 23: 209-214.

DodD, A. P. 1940. The biological campaign against prickly-pear. Commonwealth Prickly-Pear Board, Brisbane, Australia.

DodD, J. L., AND W. K. LAUENROTH. 1975. Responses of Opuntia polyacantha to water and nitrogen perturbations in the shortgrass prairie. In M. K. Wali [ed.], Prairie: a multiple view, 229-240. University of North Dakota Press, Grand Forks, ND.

DougherTy, R. L. 1986. The soil water resource of Opuntia polyacantha in semiarid grassland. Ph.D. dissertation, Colorado State University. Fort Collins, CO.

EHLERINGER, J. R., AND T. A. COOPER. 1988. Correlations between carbon isotope ratio and microhabitat in desert plants. Oecologia 76: 562-566.

Frego, K. A., AND R. J. Staniforth. 1986. Vegetation sequence on three boreal Manitoban rock outcrops and seral position of Opuntia fragilis. Canadian Journal of Botany 64: 77-84.

Goldstein, G., J. K. E. Ortega, A. Nerd, AND P. S. Nobel. 1991. Diel patterns of water potential components for the crassulacean acid metabolism plant Opuntia ficus-indica when well-watered or droughted. Plant Physiology 95: 274-280.

Grime, J. P. 1979. Plant strategies and vegetation processes. John Wiley and Sons, Toronto.

Hanscom, A., And I. P. TING. 1977. Physiological responses to irrigation in Opuntia basilaris Engelm. and Bigel. Botanical Gazette 138: 159-167.

HeInRICH, C. 1939. The cactus-feeding Phycitinae: a contribution toward a revision of the American pyralidoid moths of the family Phycitidae. In Proceedings of the United States National Museum, 131-157. Smithsonian Institution Press, Washington, DC.

Houston, W. R. 1963. Plains prickypear, weather, and grazing in the northern Great Plains. Ecology 44: 569-574.

Hyder, D. N., R. E. Bement, E. E. Remmenga, And D. F. Hervey. 1975. Ecological responses of native plants and guidelines for management of shortgrass range. USDA Technical Bulletin No. 1503, Washington, DC.

Jordon, P. W., AND P. S. Nobel. 1982. Height distributions of two species of cacti in relation to rainfall, seedling establishment, and growth. Botanical Gazette 143: 511-517.

KeEler, K. H., A. T. Harrison, and L. S. Vescio. 1980. The flora and Sandhills Prairie communities of Arapaho Prairie, Arthur County, Nebraska. Prairie Naturalist 12: 65-78. 
Koch, K. E., AND R. A. KenNEDy. 1980. Effects of seasonal changes in the Midwest on crassulacean acid metabolism (C.A.M.). Oecologia 45: 390-395.

LAUENROTH, W. K. 1979. Grassland primary production: North American grasslands in perspective. In N. R. French [ed.], Perspectives in grassland ecology. Ecological Studies 32: 3-24.

, J. L. DodD, AND P. L. Sims. 1978. The effects of water-nitrogen-induced stresses on plant community structure in a semi-arid grassland. Oecologia 36: 211-222.

Lincoln, D. E., AND J. H. LANGENHEIM. 1979. Variation of Satureja douglasii monoterpenoids in relation to light intensity and herbivory. Biochemical Systematics and Ecology 7: 289-298.

LoudA, S. M., P. M. Dixon, And N. J. Huntly. 1987. Herbivory in sun versus shade at a natural meadow-woodland ecotone in the Rocky Mountains. Vegetatio 72: 141-149.

, M. A. FARris, AND M. J. BluA. 1987. Variation in methylglucosinolate and insect damage to Cleome serrulata (Capparaceae) along a natural soil moisture gradient. Journal of Chemical Ecology 13: $569-581$

, N. J. Huntly, And P. M. Dixon. 1987. Insect herbivory in response to experimentally-induced in situ plant stress: sun versus shade. Acta Oecologia. Oecologia Generalis 8: 357-363.

, K. KeEler, AND R. D. Holt. 1990. Herbivore influences on plant performance and competitive interactions. In J. Grace and D. Tilman [eds.], Perspectives on plant competition, 413-444. Academic Press, San Diego, CA.

- AND J. E. RoDMAN. 1983a. Ecological patterns in the glucosinolate content of a native mustard, Cardamine cordifolia, in the Rocky Mountains. Journal of Chemical Ecology 9: 297-421.

, AND J. E. RoDMAN. 1983b. Concentration of glucosinolates in relation to habitat and insect herbivory for the native crucifer Cardamine cordifolia. Biochemical Systematics and Ecology 11: 199207.

Mann, J. 1969. Cactus-feeding insects and mites. U.S. Government Printing Office, Washington, DC.

Myers, D. 1981. Blue cactus borer infestation levels in three west Texas habitats. Southwestern Naturalist 26: 216-217.

NoBel, P. S. 1977. Water relations and photosynthesis of a barrel cactus, Ferrocactus acanthodes in the Colorado desert. Oecologia 27: 117-133.
1988. Environmental biology of agaves and cacti, 71-72. Cambridge University Press, New York, NY.

, P. M. Miller, AND E. A. Graham. 1992. Influence of rocks on soil temperature, soil water potential, and rooting patterns for desert succulents. Oecologia 92: 90-96.

O'BrIEN, C. W. 1970. A taxonomic revision of the genus Gerstaeckeria north of Mexico (Coleoptera: Curculionidae). Annals of the Entomological Society of America 63: 255-272.

Sala, O. E., W. J. Parton, L. A. Joyce, and W. K. Lauenroth. 1988. Primary production of the central grassland region of the United States. Ecology 69: 40-45.

SAS. 1985. SAS user's guide: statistics. Version 5. SAS Institute, Cary NC.

STRAUSS, S. Y. 1991. Indirect effects in community ecology: their definition, study and importance. Trends in Ecology and Evolution 6: 206-210.

SzareK, S. R., AND I. P. TING. 1975. Physiological responses to rainfall in Opuntia basilaris (Cactaceae). American Journal of Botany 62: 602-609.

Tilman, D. 1987. Secondary succession and the pattern of plant dominance along experimental nitrogen gradients. Ecological Monographs 57: 189-214.

TSCHIRlEY, R. H., AND R. F. WAGLE. 1964. Growth rate and population dynamics of jumping cholla (Opuntia fulgida Engelm.). Journal of the Arizona Academy of Science 3: 67-71.

USDA Soll Conservation Service. 1977. Soil survey of Arthur and Grant counties, Nebraska. U.S. Government Printing Office, Washington, DC.

VON ENDE, C. N. 1993. Repeated-measures analysis: growth and other time-dependent measures. In S. M. Scheiner, and J. Gurevitch [eds.], Design and analysis of ecological experiments, 113-137. Chapman and Hall, New York, NY.

WeAver, J. E., AND F. W. Albertson. 1936. Effects of the great drought on the prairie of Iowa, Nebraska, and Kansas. Ecology 17: 567639.

Wilhite, D. A., And K. G. Hubbard. 1989. Climate. In A. Bleed and C. Flowerday [eds.], An atlas of the Sand Hills, 17-28. Institute of Agriculture and Natural Resources, University of Nebraska, Lincoln, NE.

YeAton R. I., AND A. R. MAnZANARES. 1986. Organization of vegetation mosaics in the Acacia schaffneri-Opuntia streptacantha association, southern Chihuahuan Desert, Mexico. Journal of Ecology 74: 211-217. 